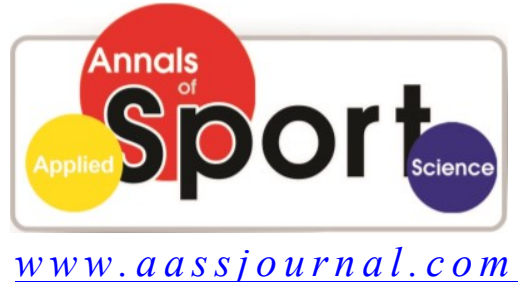

ISSN (Online): $2322-4479$

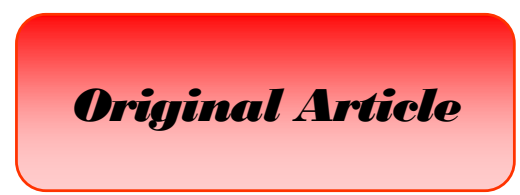

Received: $19 / 01 / 2014$

Accepted: 21/05/2014

\title{
Effective Factors on Sports Tourism: Emphasizing Development in Sports Natural Attractions
}

\author{
${ }^{1}$ Hasan Safdel, ${ }^{2}$ Mozafar Yektayar, ${ }^{3}$ Sardar Mohammadi*, ${ }^{4}$ Tayebeh Molazem
}

1. Young Researchers Club, Science and Research Branch, Islamic Azad University, Kurdistan, Iran. 2. Department of Sports Sciences, Sanandaj Branch, Islamic Azad University, Sanandaj, Iran.

3. Department of Physical Education and Sports Sciences, University of Kurdistan, Sanandaj, Iran.

4. Department of Education, Physical Education, Education District 6, Mashhad, Iran.

\begin{abstract}
The goal of this research is the evaluation of some of the effective environmental attractions on Khorasan Razavi's sports tourism development. 120 persons of all in charge expert and professors in field of sport and tourism participated in this study. Because of lack of standard tools based on research goals, after studying resources, questionnaire was designed with 50 questions and 11 subscales. Rating had been performed using Likert scale (5-item). The questionnaire included of three parts: Demographic, Attractions and Problems. The questionnaires validity had been confirmed by experts and Cronbach's alpha had been calculated as 0.82. Findings showed that effective factors on sport tourism development with emphasis on sport natural attractions is included tourism and pilgrim attractions, natural treatment and warm water attractions and summer and water sports that are the most important items in Khorasan Razavi. Also there are three important factors in relation to problems and obstacles as Management problems, cultural problems and infrastructure problems. Research results show that pilgrim locations are effective to attract tourists and knowing the effects of tourism industry development and present of obstacles and limitation in the province, attention to sport tourism development importance and applying various benefits of sport tourist attraction are necessary and programming and sport tourism developments by province planner and policy makers would be required.
\end{abstract}

Key Words: Tourism, Sport Tourism, Sport Natural, Attractions, Problems.

Corresponding Author:

Sardar Mohammadi

E-mail: sardarmohammadii@gmail.com 


\section{INTRODUCTION}

Today, tourism is one of the basic world economic activities to achieve much revenue. Comparing to other economic sectors and with creation of new employment opportunities this industry is faced to more quick growth and this is pioneer industry (1). Today, tourism is very important factor to country social and economic development, therefore, this is named as non-visible export (2).

Based on most important revenue research categorization of the world, petroleum exploration and exploitation industry is the richest industry. Then, automobile manufacturing and after that, tourist would be defined (3).

Human paid attention to tourism industry from long time ago. Therefore, this industry has important role in world economy. Also this is effective factor to cultural interaction, nation conversation and creating relation among nations. According to world tourism organization prediction more than $\% 43$ of world occupations would be related to tourism industry until 2011 (4) one of the important sectors that could be developed would be sport in tourism industry (5).

In some of countries $25 \%$ of total tourism revenue is related to sport and because of its economic and political role this is important applied issue (6). Today to manage and plan to urban and provincial locations dynamic and systematic view point would be required. Therefore using tools and compiled approaches, the motives would be identified and applied to achieve goals. Evaluation and analysis of capabilities and resource show first important step to develop and manage sport tourism goals.

The framework is suggested by Higham and Hinch (2009), and the exercise as the main focus and attraction is located. In this framework, there are three basic dimensions of "sport then", "next time" and "space after" (7). Gibson (1998), and Gammon and Robinson (2003) considered tourism and sporting in a wide range of human activities in natural, which is also due to the vast amount of natural attractions of the sport in the country and can serve as an important source of increased level of sports tourism in the country (although in the tourism and sports tourism in the past) $(8,9)$. The system as well as the tourist attraction Hinch and Higham (2011), according to numerous studies in various aspects of multilateral overt and covert sports tourism as well as to represent (10).

Various goals include properties attraction and capabilities of tourism and sport to develop and attract sport tourism $(11,12)$; therefore, sport and tourism are two critical elements of global economy that affected modern society developing sport activities and coordination between sport and tourism benefits (13).

Sport tourism term was innovated to create better understanding about sport as tourism motivation $(14,15)$. According to world tourism organization statistics $43 \%$ of world occupation is related to tourism industry. For example, during 1997 to 2005, sport tourism lead to annual 13\% increase of national gross production that is as a result of economic activities.

According to holding great sport competitions, annual 19\% unemployment decreases had been achieved (16). According to above issues, statistics show most of world countries have appropriate condition about sport tourist and manage great part of their economies through sport tourism economy $(17,18)$. Iran is one of the ten countries due to tourism variety (19). Therefore, in recent research, manager and expert viewpoints would be evaluated about sports tourism development with emphasis on sport natural attraction development in Khorasan Razavi; therefore, evaluation sports tourism industry development effects, organization cooperation to sport tourism, province sports tourism capabilities assessment and sport 
natural attraction priorities evaluation have been performed to determine province problems and obstacles and help to managers and in charges to provide this industry development approaches and plans.

\section{MATERIALS AND METHODS}

This research type is descriptive post event based on field method.

Participants. 120 persons experts of tourism organization, cultural heritage and handmade industries, public body training departments, education body training departments, sport boards (mountain climbing, boating, swimming, horseback riding, bicycle driving, archery, running race, public sports, ski, golf), high education body training center, body training professor having certificate in field of body training and sport sciences management in Khorasan Razavi province are participated in this research.

Tools. According to research nature as descriptive-post event, research tools included of questionnaire; because of lack of standard tools based on research goals, after studying resources, questionnaire was designed with 50 questions and 11 sub-scales. Rating had been performed using Likert scale (5-item). The questionnaire included of three parts: Demographic, Attractions and Problems. First part included related questions to personal specifications and second part include of 50 questions: 30 questions were related to natural sport attractions and 20 questions were related to tourism problems. The questionnaire had been used to determine validity among 15 person of professor and tourism and sport management experts obtaining the ideas of them, their view points and recommendations had been included in preliminary questionnaire. Performing guide research, questionnaire reliability had been determined using Cronbach's alpha method (0.82) and its stability had been confirmed.

Statistical Analysis. Normality assumption were analyzed using Kolmogorov-Smirnov, and one-sample t-test and Friedman was used to examine the hypothesis of the study. Significance levels accepted at $p<0.05$. All statistical analyses were performed using Statistical Package for Social Sciences (SPSS) software.

\section{RESULTS}

The participants' demographic information are descriptively are presented in Table 1.

Table 1. Demographic information of the participants

\begin{tabular}{ccccc}
\hline Variables & Classification & Frequency & Percentage & Mean \pm SD \\
\hline \multirow{2}{*}{ Gender } & Man & 78 & 65 & \\
& Woman & 36 & 30 & \\
\hline Age & & & & $37.98 \pm 7.66$ \\
(Years Old) & & & & \\
\hline \multirow{2}{*}{ Education level } & Associate's degree & 22 & 18.33 & \\
& Bachelor's degree & 59 & 49.16 & \\
& Master's \& PhD & 32 & 26.66 & \\
\hline Work Experience & & & & $12.01 \pm 7.15$ \\
(Years) & & & & \\
\hline
\end{tabular}

Ranking analysis with Friedman test for sport natural attraction dimensions show that religious traveling attraction with 6.21 mean rank, warm water and nature treatment with
5.3, summer and water sports attraction with 4.43 , mountain climbing and nature visit with 4.33, hunting attraction with 4.26 , care visit attraction with 3.97 , winter sports attraction 
with 3.77 , and so desert visit attraction with 3.74 mean rank, had significant $(\mathrm{x} 2=70.44$, $\mathrm{df}=7, \mathrm{p}=0.001$ ) higher to lower priority on sports tourism development of Khorasan Razavi province in Iran (table 2).

Table2. priorities of environmental attraction dimensions on sport tourism development

\begin{tabular}{lcc}
\multicolumn{1}{c}{ Factors } & Mean Rank & Priority \\
\hline Impact attractions of tourism and pilgrimage & 6.21 & $1^{\text {st }}$ \\
\hline Effect of heat and natural attractions water treatment & 5.3 & $2^{\text {nd }}$ \\
\hline Effects of hunting and fishing attractions & 4.43 & $3^{\text {rd }}$ \\
\hline tourism attractions of the desert & 4.33 & $4^{\text {th }}$ \\
\hline The effect of gravity hills climbing and nature tourism & 4.26 & $5^{\text {th }}$ \\
\hline The effect of gravity mountain climbing and caving & 3.97 & $6^{\text {th }}$ \\
\hline The effect of gravity winter sports & 3.77 & $7^{\text {th }}$ \\
\hline Effect of water sports and summer attractions & 3.74 & $8^{\text {th }}$ \\
\hline
\end{tabular}

Also, ranking analysis with Friedman test for sport tourism problem dimensions show that management-related problems with 2.44 mean rank, cultural and tourism problems with 1.84, and infrastructures-related problems with 1.72 mean rank had significant $(\mathrm{x} 2=$ 25.161 , df $=2, p=0.001$ ) higher to lower priority on sports tourism development of Khorasan Razavi province in Iran (table 3).

Table3. priorities of sport tourism problem dimensions on sport tourism development

\begin{tabular}{c|c|c}
\hline Factors & Mean Rank & Priority \\
\hline Problems related to management & 2.44 & $1^{\text {st }}$ \\
\hline Problems related to Tourism and Culture & 1.84 & $2^{\text {nd }}$ \\
\hline Problems with the substructure & 1.72 & $3^{\text {rd }}$ \\
\hline
\end{tabular}

\section{DISCUSSION AND CONCLUSION}

Sport tourism as the part of tourism industry that may be transferred to the first industry with highest revenue in the world. According to this issue that sport tourism using sport natural attraction can create positive and negative effects, identification of effective activities and related social and environmental effects would be necessary $(20,21)$. According to natural views' caves, mountains, great water series, road, positioning in Abrisham road and religious locations, there is special attraction to absorb sport tourist. Research findings show that from expert and managers view points, religious- traveling attraction, warm water and nature treatment, summer and water sport attractions are the most important attraction to Khorasan Razavi sport tourism development. Findings are in conformance to Mafei and
Zafaranlo (2013), Miranda and Andueza (2005), Weed (2006), and Kozak (2002) (3, 15, $18,22)$.

Due to having religious location, this province is attractive. Because of importance and religious role, cultural religious performance of province and Mashhad had been affected. From sport expert view point, this is the most important factor that is defined as first priority route to sport tourism industry development.

Research findings are in conformity to findings of Sardi Mahakan (2001), Moumeni, Sarafi, and Ghasemi Khouzani (2008) $(12,19)$. Presences in some of the events or sport tourism location lead to reinforce cultural desires and formalities based on specific beliefs. These factors lead tourists to travel $(22,23)$. According to Kim, Gursoy, and Lee (2006) one 
of the positive effects of world cup football 2002 on South Korea was a cultural development and positive interaction (16).

According to research findings and other results, proper conditions should be provided to supply requirements based on motives and honor to culture and beliefs of sport tourists as human duty. Sport tourism development potentials of any location would be determined based on required resources and infrastructures. Sport tourism resource list include of physical environment sport equipment, tourism transportation capabilities and infrastructure (24). Therefore province direction should invest to develop infrastructures as transportation, location, sport facilities, facility capabilities, welfare capabilities, residential possibility, sport location quantity, conformity between locations and facilities to national and international standards, construction of sport location to cover various purposes to hold sport events, non- competitive and recreational activities to use tourists.

These issues should be emphasized in programming, approach determination and development of this industry at future. Hypothesis analysis findings show tourism problems are effective on Khorasan Razavi tourism development.

Expert viewpoints about prioritization show the effect of related problems to management as 2.44, tourism and cultural problems with 1.84 and related problems to infrastructures with 1.72 as the most important factors on Khorasan Razavi sport tourism development. These issues show that tourism domain problems have significant Effects on tourism development condition these findings are in conformity to researches of Ebrahimzadeh and Aghasizadeh (2009), Mohseni (2010) Madhoshi and Niyazi (2010), Adabi Firouzjah, Kouzehchian, and Ehsani (2009), and Madhoushi and Naserpour (2003) confirmed that management weakness is obstacle to sport tourism industry $(6,25-28)$.

It is necessary to note that tourism domain problems should be evaluated from various angles using applied and scientific approaches, these problems would be eliminated.

According to this issue that sport tourism science is young and applied, to achieve cultural and economic goals, we should perform scientific and exact evaluations to obtain significant progress in sport tourism and absorb local and foreign tourists $(1,28)$.

According to global importance of sport tourism, the country having various natural views could be basic pole in the world to absorb millions tourists. Therefore, civil and economic progress of attractive locations would be achieved. In fact to eliminate obstacles of sport tourism plans and its development, it is recommended to pay attention to experiences of various countries about sport tourism and opinions of organization expert and managers in relation to country and province sport tourism.

To develop sport tourism in Khorasan Razavi, proper organizational structural condition should be managed. Having management and rational and proportional planning based on province condition would help to perform approaches and achieve to goals in field of sport tourism development. More infrastructure development as establishment of location to tourists and having welfare capabilities and health food and air and attention to environmental attractions would be effective on province tourism progress. Therefore, it is recommended in environmental domain attractions, expert personal should be applied to promote conditions and improve sport tourism situation.

In fact supporting official and political managers in relation to province sport tourism development, introducing sport tourism and tourism industry to people using marketing and advertisement, table and billboards in public location, city entry and exit and publishing poster manual, books and creating systematic relations between body training organization, Iran trade development organization and cultural heritage and tourism organization and coordination and interaction between various 
organs as environment, cultural heritage sport boards, body training department and universities to improve condition would be necessary.

Establishment of university specialized course with concept of sport tourism in province and using sport event hosts, creating opportunity to employee and train most of volunteers to help management and official affairs domain, presence of investors in various economic sectors as sport tourism and providing new sport tourism products, determination of independent organ to decision making in country sport tourism with tourism, sport and marketing using modern technology, compiling agreement between body training organization and tourism and cultural heritage organization and broadcast to advertising sport tourism attractions would be effective. according to importance of sport tourism and necessity of using personal, economic, social, cultural and political benefits, it is confirmed that managers and policy makers and planners of sport tourism affairs should attempt and cooperate to province governor, governorship, municipality, tourism department, body training department, natural resource departments of province and cities to introduce and develop sport and recreational attraction and promotion of necessary infrastructures to develop this industry with regional and district management.

To achieve this goal, more familiarity of managers and in charges would be necessary beside to understanding importance of absorbing sport tourists to overall development of various parts of province.

\section{REFFRENCES}

1. World Tourism Organization. Yearbook of Tourism Statistics: World Tourism Organization; 2008.

2. Chalip L, Green B, editors. Leveraging large sports events for tourism: Lessons learned from the Sydney Olympics. Supplemental proceedings of the Travel and Tourism Research Association 32nd Annual Conference; 2001.

3. Miranda J, Andueza J. The role of sport in the tourism destinations chosen by tourists visiting Spain. Journal of Sport \& Tourism. 2005;10(2):143-5.

4. Chen CM, Lee HT, Chen SH, Huang TH. Tourist behavioural intentions in relation to service quality and customer satisfaction in Kinmen National Park, Taiwan. International Journal of Tourism Research. 2011;13(5):416-32.

5. Funk DC, Bruun TJ. The role of socio-psychological and culture-education motives in marketing international sport tourism: A cross-cultural perspective. Tourism Management. 2007;28(3):806-19.

6. Ebrahimzadeh E, Aghasizadeh A. The Analysis of Effective Factors in the Expansion of Coastal Region of Chabahar Tourism through SWOT Model. Urban-Regional Studies and Research. 2009;1(1):107-28 [Article in Farsi].

7. Higham J, Hinch T. Sport and Tourism: Globalization, Mobility and Identity: Butterworth-Heinemann/Elsevier; 2009. 314 p.

8. Gammon S, Robinson T. Sport and Tourism: A Conceptual Framework. Journal of Sport \& Tourism. 2003;8(1):216.

9. Gibson HJ. Sport Tourism: A Critical Analysis of Research. Sport Management Review. 1998;1(1):45-76.

10. Hinch T, Higham J. Sport Tourism Development: Channel View Publications; 2011. 258 p.

11. Kasimati E, Dawson P. Assessing the impact of the 2004 Olympic Games on the Greek economy: A small macroeconometric model. Economic Modelling. 2009;26(1):139-46.

12. Moumeni M, Sarafi M, Ghasemi Khouzani M. The Structure and Function of Religious-Cultural Tourism and the Necessity of Integrated Management in Mashhad Metropolis. Geography and Development. 2008;6(11):13-38 [Article in Farsi].

13. Honavrar A, Moshref Javadi B, Ghafouri F. Push Factors for Tourists to Visit International Sport Events in Iran. Olympic. 2005;13(3):51-64 [Article in Farsi].

14. Hritz N, Ross C. The perceived impacts of sport tourism: An urban host community perspective. Journal of Sport Management. 2010;24(2):119-38.

15. Weed M. Sport Tourism and the Development of Sport Events UK: www.idrottsforum.org; 2006 [cited 2014 ]. Available from: http://idrottsforum.org/articles/weed/weed061213.pdf.

16. Kim HJ, Gursoy D, Lee S-B. The impact of the 2002 World Cup on South Korea: comparisons of pre- and postgames. Tourism Management. 2006;27(1):86-96. 
17. Gee CY, Solá EF. International Tourism: A Global Perspective: World Tourism Organization; 1997.

18. Kozak M. Comparative analysis of tourist motivations by nationality and destinations. Tourism Management. 2002;23(3):221-32.

19. Sardi A, Mahakan. The role of marketer in the tourism industry of Mashhad. Tehran, Iran: Tarbiat Modares University; 2001 [Thesis in Farsi].

20. Razavi SMH, Hosseini SE, Khajehpour A. The natural attractions affecting development of sports tourism of the Mazandaran province. Bulletin of Sport Management \& Motor Behavior. 2013;9(17):15-26 [Article in Farsi].

21. Lumsden L. Tourism marketing. London: Thompson; 1997.

22. Mafei E, Zafaranlo A. Analyzing and Ranking Urban Tourist attractions in Mashhad by Emphasizing on Fuzzy Multi-criteria Decision Making (Fuzzy MCDM). World of Sciences Journal. 2013;1(13):170-85.

23. Shahidi M.Sh. AZAS, Goudarzi Soroush M.M. An Investigation of the Role of Tourism in Rural Areas (Case Study: Dehestan Lavasan). Human Geography Research Quarterly. 2009(67):99-113 [Article in Farsi].

24. Swart K, Bob U. The Eluding Link: Toward Developing a National Sport Tourism Strategy in South Africa Beyond 2010. Politikon. 2007;34(3):373-91.

25. Adabi Firouzjah J, Kouzehchian H, Ehsani M. A Study of the Effect of Natural Sport Attractions on Developing Sport Tourism in Iran from the Viewpoint of the Sport and Tourism Experts. Journal of Sport Management. 2009;1(1):67-81 [Article in Farsi].

26. Madhoshi M, Niyazi E. Investigatinng and Specifying the Development of Tourism Industry in Golestan Province. Knowledge And Development. 2010;17(30):135-62 [Article in Farsi].

27. Madhoushi M, Naserpour N. Survey of the Effective Factors to the Underdevelopment of Lorestan Province Tourism Industry. Iranian Journal of Trade Studies (Ijts). 2003;7(28):25-58 [Article in Farsi].

28. Mohseni RA. Sustainable Tourism in Iran: Functions, Challenges and Solutions. Geographic Space. 2010;9(28):149-71 [Article in Farsi]. 
تازههاى علوم كاربردى ورزش

مقاله اصيل

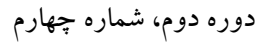

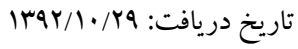

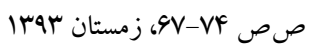

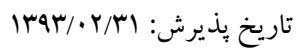

\section{عوامل مؤثر بر كر دشَّى ورزشى: با تأكيد بر توسعه جذابيت ورزش هاى در طبيعت}

\section{'حسن صافدل، 'مظفر يكتايار، 'سردار محمدى *؛ "طيبه ملازم}

ا. كارشناسى ارشد مديريت ورزشى، باشكاه يزوهشگران جوان، دانشخاه آزاد اسلامى، واحد علوم و تحقيقات كردستان، سندج، ايران.

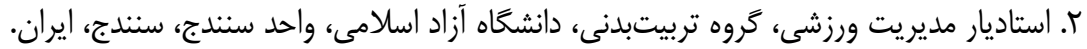

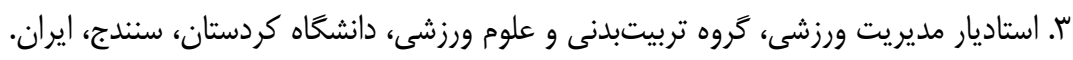

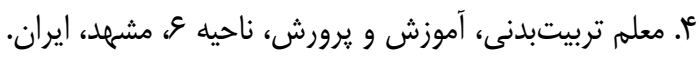

جكيده

هدف از تحقيق حاضر بررسى برخى از جذابيتهاى طبيعى مؤثر بر توسعه كردشكرى ورزشى استان خراسان رضوى بود. تعداد • rا نفر از

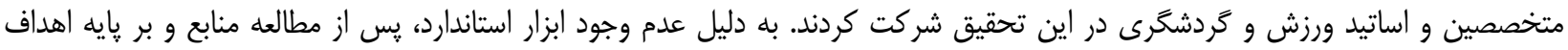

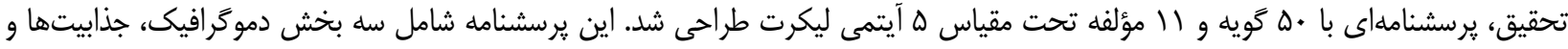

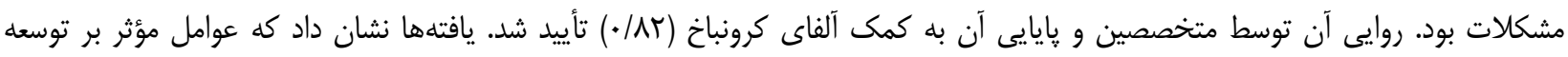

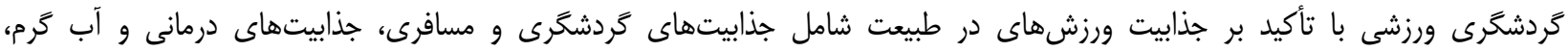

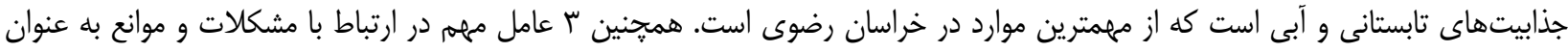

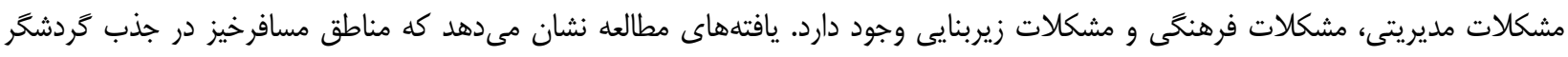

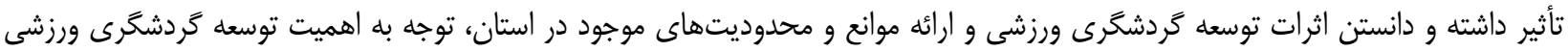

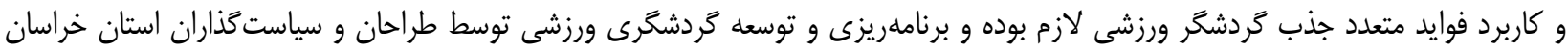
رضوى ضرورى مى باشد. وازَّان كليدى: كَردشَّى، كردشكَى ورى ورشى، ورزش در طبيعت، جذابيتها، مشكلات. 